\title{
Academic Staff Disposition To Promotion Criteria In Nigerian Universities
}

\author{
Ijeoma A. Archibong, Cross River University of Technology, Nigeria \\ David, O. Effiom, Cross River University of Technology, Nigeria \\ Don Omoike, Ambrose Ali University, Nigeria \\ Aniefiok O. Edet, University of Calabar, Nigeria
}

\begin{abstract}
This study aimed at determining academic staff satisfaction with promotion criteria and what, in their view, should be included in the promotion criteria. A researcher-designed questionnaire was utilized for data collection from a sample size of 349 academic staff. Findings show that the majority of the academic staff were dissatisfied with the promotion practices. Academic staff were satisfied with promotion criteria that had to do with required number of publications but dissatisfied with those related to computer literacy and international publication requirements. An oral interview before promotion was advocated for inclusion into the promotion criteria by academic staff. Evolving a more holistic criterion for promotion of academic staff was recommended.
\end{abstract}

Keywords: Academic staff disposition, academic staff satisfaction, promotion criteria, Promotion procedure, promotion criteria inclusion

\section{INTRODUCTION}

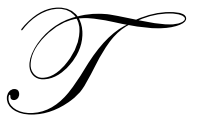

he principal role of the university revolves around three key functions; namely, advancement of knowledge through research, dissemination of knowledge through teaching, and community service. These key functions are intended to bring about national development and competitive advantage to a country at the global level. The achievement of these objectives, to a large extent, depends on the academic staff because of the critical role they play in the educational process. How effectively an academic staff performs the above-mentioned functions is often the core basis for promotion in Nigerian universities. Promotion of an academic staff from a lower rank to a higher one is an indication that the staff has shown evidence of scholarship and effective performance in all the criteria for promotion as stipulated by the university policy. However, according to Owuamanam and Owuamanam (2008), assessment of productivity in Nigerian universities is based mainly on research and publications rather than teaching competence alone, and consequently, advancement in the job depends mainly on the individual's research output. Similarly, the respondents in a study by Drennan and Beck (2000) indicated that while the universities' stated policies are to assess a candidate for promotion on the basis of his or her ability in three main criteria - teaching, administration and research - it was the latter which appeared to be attributed the greatest weighting. Still, on criteria for academic staff promotion, Badri and Abdulla (2004) hold that academic staff appraisal can also be evaluated through items, such as research articles produced, teaching method, presentation style, and involvement in university and community activities. The process of decision-making for academic staff promotion often involves criteria, such as tasks, activities, teaching, supervision, publications, research, consulting, conferencing, administration, and community service (Salmuni, Mustaffa and Kamis, 2007).

Regardless of what the procedure for promotion entails, the incentives and reward system operating in higher educational institutions has often been associated with staff motivation and performance on the job. Salmuni, Mustaffa and Kamis (2007) assert that the most attractive reward perceived by the staff is still promotion and that promotion will improve the staff objective and performance. Santhapparaj and Alam (2005) found that promotion has a positive and significant effect on job satisfaction. In line with this view, Ubeku (1975) had earlier asserted that promotion brings along with it not just more money, but also a mark of recognition of an individual's performance 
and that the motivating effect of promotion is high. Similarly, Turk (2008) upholds that a good and well functioning performance appraisal system would help the educators to make their mark in the organizational setting of their faculty.

\section{THE PROMOTION PROCEDURE}

The following is the promotion process for academic staff in most Nigerian public universities:

1. Evaluation by the Departmental Appointments and Promotions Committee (Academics). This committee has the Head of Department as chairman and all lecturers from the rank of senior lecturer upward who are not candidates as members. The assessment made by the Head of Department for individual candidate along with the recommendations of the Departmental Appointment and Promotion Committee based on established criteria is forwarded to the Dean.

2. Evaluation by the Faculty Appointments and Promotions Committee (Academics). This committee consists of the Dean as chairman, all Heads of Departments and all Professors in the faculty as members and the Faculty officer as secretary. This committee assesses the candidate based on the guiding criteria putting into consideration the recommendations from the Departmental Appointments and Promotions Committee. The committee's recommendations are forwarded to the Central Appointments and Promotions Committee (Academics).

3. Evaluation by the Central Appointments and Promotions Committee. This committee comprises the ViceChancellor as chairman, Deputy Vice-Chancellor (academics), two external council members, all Deans/Directors/Provost, Registrar, University Librarian as members and Deputy Registrar (Establishment / Personnel) as secretary. This committee in line with the laid down criteria appraises the candidate putting into consideration the forwarded reports and recommendations from the Faculty Appointments and Promotions Committee.

\section{GENERAL PROMOTION CRITERIA} procedure:

The following guiding criteria for promotion apply to all cadres of academic staff in the promotion

- A favourable report from the Departmental Appointment and Promotion Committee and the Head of Department.

- A favourable report from the Faculty Appointment and Promotion Committee.

- $\quad$ A waiting period of three years at each rank before qualification for promotion.

- Possession of Ph.D degree is mandatory for candidates for Readership and Professor. Promotion to other ranks below Readership can be attained with a Masters degree with course work and thesis and four years of teaching experience at each level.

- $\quad$ Stipulated number of publications in reputable journals and/ or in standard texts.

- $\quad$ Two positive reports from external assessors are required for candidates up for promotion to either Reader or professor.

\section{STATEMENT OF THE PROBLEM}

Over the decades, several scholars have undertaken studies relating to academic staff promotion, its influence on their job satisfaction and motivation. As far back as 1986, Moses (1986) reported that research studies in the USA, Britain, Australia and New Zealand which examined academic staff members' attitude to the promotion procedure in their institutions found dissatisfaction with existing practices. While Owuamanam and Owuamanam (2008) maintain that there is still doubt raised regarding the adequacy and objectivity of the criteria for employment and promotion. The present study aims at determining specific criteria for promotion that academic staff members are satisfied with or otherwise, and what items in their opinions should be added to the promotion criteria. 


\section{RESEARCH QUESTIONS}

In order to achieve the stated aims of this study, the following research questions are posed:

1. What percentage of the academic staff members are satisfied with the promotion practices in their institutions?

2. How satisfied are the academic staff with the promotion criteria?

3. What in academic staff members' opinions should be included to the promotion criteria?

\section{RESEARCH PROCEDURE}

The research design adopted for this study was survey. The study involved the utilization of academic staff in 3 Nigerian public universities namely- Ambrose Ali university (AAU) Ekpoma, Cross River University of Technology (CRUTECH), Calabar and University of Calabar (UNICAL). The population for the study comprised all academic staff in the named institutions. Simple random sampling was employed to select 3 Faculties per university. In AAU, these were Faculties of Education, Social Sciences and Engineering. In CRUTECH, they included Faculties of Education, Environmental Sciences and Engineering, while those of UNICAL were Faculties of Education, Social Sciences and Sciences. Stratified random sampling was utilized in selecting 50 per cent of academic staff in each Department that make up the Faculties. This was applied to Faculties that had more than 50 academic staff. Where the academic staff was less than 50 in the sampled Faculty, all the academic staff members were utilized. The process yielded a sample size of 135 academic staff members in AAU, 129 for CRUTECH and 119 for UNICAL. This gave a total sample size 383 respondents. A total of 349 academic staff members completed and returned their questionnaires, representing a response rate of approximately $91 \%$. Of his number, 142 were females while 207 were males.

Data were collected with the aid of research instrument developed and validated by the researcher tagged 'Promotion Criteria Questionnaire' (PCQ). The instrument was face validated by 2 educational researchers, while the test-retest technique using 40 academic staff that were not part of the study sample yielded a reliability coefficient of 0.69. Section A of the questionnaire sought demographic information such as gender, while section B contained 3 items. Item 1 required a 'yes or no' response. Item 2 contained list of promotion criteria and required respondents to indicate their degree of satisfaction with the stated criteria on a scale of 4 points, that is, from 'very satisfied' to 'not satisfied'. Item 3 was an open ended question which required the subjects to suggest what should be included in the promotion criteria.

Descriptive statistics (Percentages, Mean and Standard deviation) were used for data analysis. An item with a Mean rating of 2.5 was regarded as significant, while a Mean rating below 2.5 was regarded as not significant.

\section{RESULTS AND DISCUSSION}

Research question 1 - What percentage of the academic staff members are satisfied with the promotion practices in their institutions?

The data collected with regard to this research question were analysed using percentages and the obtained result is presented in Table 1.

Table 1: Respondents' Satisfaction with Promotion Practices $(n=349)$

\begin{tabular}{|cc|}
\hline Yes & No \\
$96(27.5 \%)$ & $253(72.5 \%)$ \\
\hline \hline
\end{tabular}

The answer to the question 'are you satisfied with the promotion practices in your institution' is presented in Table 1, which shows that 96 respondents representing $27.5 \%$ were satisfied with the promotion practices in their institutions, while $253(75.5 \%)$ were not satisfied. This result depicts that the majority of the academic staff 
members are not satisfied with the promotion practices in their institutions. This finding can be attributed to the 'publish or perish' phenomena existing in Nigerian universities. The result reflects academic staff discontentment with much emphasis and weighting given to publications in the promotion process to the detriment of other core functions that the academic staff perform.

Research question 2 - How satisfied are the academic staff with the promotion criteria?

Academic staff satisfaction with the various indices of promotion was analysed by determining their Mean score and standard deviation (SD) and then rank ordered. The result is shown in Table 2.

Table 2: Mean Score and Ranking of Academic Staff Satisfaction with Promotion Criteria

\begin{tabular}{|l|c|c|c|c|}
\hline \multicolumn{1}{|c|}{ Promotion criteria } & N & Mean & SD & Rank \\
\hline \hline Head of Department's assessment & 349 & 3.03 & 0.81 & $1^{\text {st }}$ \\
\hline Faculty A \& PC assessment & 349 & 2.93 & 0.85 & $2^{\text {nd }}$ \\
\hline Three year gap before next promotion & 349 & 2.75 & 0.96 & $3^{\text {rd }}$ \\
\hline Number of required publications & 349 & 2.47 & 1.02 & $4^{\text {th }}$ \\
\hline Teaching & 349 & 2.46 & 0.88 & $5^{\text {th }}$ \\
\hline Community service & 349 & 2.40 & 0.86 & $6^{\text {th }}$ \\
\hline Conference attendance & 349 & 2.39 & 0.96 & $7^{\text {th }}$ \\
\hline University administration & 349 & 2.27 & 0.85 & $8^{\text {th }}$ \\
\hline Learned society belongingness & 349 & 2.22 & 0.92 & $9^{\text {th }}$ \\
\hline International publication requirement & 349 & 2.14 & 1.02 & $10^{\text {th }}$ \\
\hline Supervision of graduate work & 349 & 2.11 & 1.12 & $11^{\text {th }}$ \\
\hline Computer literacy & 349 & 2.04 & 0.99 & $12^{\text {th }}$ \\
\hline \hline
\end{tabular}

Results in Table 2 show that the head of department's assessment ranked first among the promotion criteria that academic staff are satisfied with. During the promotion process, the head of department is required to comment on the candidate under the following headings: assessment of publications; assessment of research; assessment of teaching; willingness to accept responsibility; attitude to students; attitude to colleagues in the department and community service. Academic staff satisfaction with their heads of departments' assessment during the promotion process could be explained by the fact that heads of departments have personal knowledge of staff and as such could give a valid assessment about them. The same reason could be tenable for the result on Faculty Appointments and Promotions Committee which is ranked second on the list of criteria since most of the recommendations from the Departmental Appointments and Promotions Committee are often affirmed at the Faculty level. Although this is often the case, the onus is on the Faculty Appointments and Promotions Committee to further scrutinize each candidate's presentation particularly in the areas of quality of journal and spread of publication.

Academic staff satisfaction with number of years spent on a particular level before the next promotion and the required number of publications which was ranked third and fourth respectively, may be due to the fact that these two criteria is same for all academic staff of same cadre and so no staff has any reason to complain about them. Academic staff satisfaction with teaching as a requirement for promotion is moderate (Mean $=2.46)$. The plausible reason could be that in most Nigerian public universities, teaching is only noted but not scored or in some cases the score allotted to teaching is very negligible when compared to that of publications. This finding is in line with the works of Moses (1986) and Over (1993) which revealed that academic staff are dissatisfied with the undervaluing of teaching and that universities are more interested in publications than in scholarship. Similarly, this result in line with the assertion of Volkwein and Carbone (1994) that academic staff are recruited primarily to teach, but are given promotion and salary increase, based primarily on their research and scholarship.

Academic staff dissatisfaction with community service, conference attendance, university administration participation and belongingness to learned society could be attributed to the fact that these aspects of promotion criteria require some level of expenditure which staff are unwilling to undertake given their low income and limited sponsorship opportunity for conferences. Regardless of funding challenge, academic staff that neglect actively belonging and participating in professional bodies related to their discipline implies that they miss out on 
opportunity of interacting with like-minded professionals, updating their knowledge, and establishing links that will give them access to information.

With regard to university administration, academic staff often perceive it as a thankless job which takes a lot of one's time, energy and personal monies without much reward and attracts no score during assessment for promotion. In the same vein, international publications ranked low because of the stress in terms of cost and inconveniences that staff encounter in getting their works published outside Nigeria. Supervision of graduate work ranked low probably because academic staff feel it is an unfair criteria since some department rarely get post graduate enrolment, thus making it difficult for academic staff to meet this requirement. Academic staff dissatisfaction with computer literacy which ranked last could be attributed to the obstacles such as weak infrastructures, lack of access to ICT facilities, lack of training opportunities etc. earlier reported by Archibong and Effiom (2009). These challenges notwithstanding, academic staff with negative disposition to ICT need to consider its great benefits as succinctly stated by Carlson and Gadio (2000) that teachers who succeed in making use of ICT in their work process do not only contribute to improved learning outcomes in their students, but also benefit personally from enhanced work productivity, reduced isolation and increased professional satisfaction.

Research question 3 - What in academic staff members' opinions should be included to the promotion criteria?

The suggested criteria for inclusion in the promotion process by academic staff are presented in Table 3 .

Table 3: Suggested inclusion into the promotion criteria

\begin{tabular}{ll}
\hline \hline- & Oral interview before promotion \\
$\bullet$ & Assessment of academic staff by students \\
$\bullet$ & Evidence of active participation in professional body activities \\
- & Allotting equitable score to all the criteria \\
$\bullet$ & Increasing the scoring for teaching \\
\hline \hline
\end{tabular}

With regard to research question 3, most staff opined that the depicted criteria in Table 3 should be added to the promotion criteria. Most of the suggested criteria for inclusion are not strange given the benefits that can accrue as a result of their inclusion. Oral interview for instance, reveals the authenticity of the candidate's claims, while student assessment gives feedback on teaching. Again, participation in professional activities and sabbatical leave affords an academic staff the opportunity to interact with others in the same field of specialization, thereby improving their skills and providing them networking opportunities.

\section{CONCLUSION}

From the findings in this study, the following conclusions are drawn:

1. Most academic staff in Nigerian public universities are not satisfied with the promotion practices.

2. Academic staff are very satisfied with the components of the promotion criteria that had to do with Head of Department's assessment, Faculty Appointments and Promotion Committee assessment, number of years spent on a particular level before the next promotion and required number of publications.

3. Academic staff are most dissatisfied with the promotion criteria that relates to computer literacy, graduate work supervision and international publication requirement.

\section{RECOMMENDATIONS}

Based on the findings, it is hereby recommended that university management should take a critical look at the promotion practices in their institutions with a view to evolving a more holistic approach to academic staff assessment for promotion and thereby addressing areas of dissatisfaction expressed by academic staff. In doing this, 
the suggested inclusion into the promotion criteria should be taken into consideration particularly teaching and services to the community and with equitable weighting of the various sub-heads in the appraisal form.

\section{AUTHOR INFORMATION}

Dr Ijeoma A. Archibong majors in Administration in higher education and is currently a Senior Lecturer in the Department of Educational Foundations \& Administration, Cross River University of Technology. Nigeria

Dr David O. Effiom majors in Guidance \& Counselling and is currently a Senior Lecturer in the Department of Educational Foundations \& Administration, Cross River University of Technology. Nigeria

Dr Don Omoike majors in Educational Administration and is currently a Senior Lecturer in the Department of Educational Foundations \& Management, Ambrose Ali University, Ekpoma, Nigeria

Dr Aniefiok O. Edet majors in Educational Administration and Planning and lectures in the Department of Educational Administration \& Planning, University of Calabar, Nigeria.

\section{REFERENCES}

1. Archibong, I. A. \& Effiom, D. O. (2009). ICT in university education: Usage and challenges among academic staff. African Research Review. 3(2), $404-414$.

2. Badri, A. M \& Abdulla, H. M. (2004). Awards of excellence in institution of higher education: An AHP approach. International Journal of Educational Management. 18(4), 224 - 242.

3. Carlson, S. \& Gadio, C. T. (2002). Teacher professional development in the use of ICT. In Haddad, W. D. \& Draxler, A. (Eds.), Technology for education. (pp. 118 - 132). Washington, DC: UNESCO; Academy for educational development.

4. Drennan, L. T. \& Beck, M. (2000). Teaching and research- equal partners or poor relations? Paper presented at the Quality Evidence-based practice conference, Coventry University, May 15-17.

5. $\quad$ Moses, I. (1986). Promotion of academic staff. Higher Education. 15 (1-2), 134-149.

6. Owuamanam, D. O. \& Owuamanam, T. O. (2008). Sustaining academic progress through objective evaluation of research in Nigeria. College Teaching Methods \& Styles Journal. 4(8), 27 - 31.

7. Salmuni, W., Mustaffa, W. \& Kamis H. (2007). Prioritizing academic staff performance criteria in higher education institutions to global standards. Proceedings of the $13^{\text {th }}$ Asia Pacific Management Conference, Melbourne, Australia, 2007, 1281 - 1288.

8. Santhapparaj, A. S. \& Alam, S. S. (2005). Job satisfaction among academic staff in private universities in Malaysia. Journal of Social Sciences. 1(2), 72 -76.

9. Turk, K. (2008). Performance appraisal and compensation of academic staff in the University of Tartu. Baltic Journal of Management. 3(1) 40 - 54.

10. Ubeku, A. K. (1975). Personnel Management in Nigeria. Benin City: Ethiope publishing company.

11. Volkwein, J. F. \& Carbone, D. A. (1994). The impact of departmental research and teaching climate on undergraduate growth and satisfaction. Journal of Higher Education. 65(2), 147 - 167. 